\title{
A DIGNIDADE DA PESSOA HUMANA E A MULHER NO CÁRCERE BRASILEIRO: UMA ANÁLISE A PARTIR DOS DIREITOS DA PERSONALIDADE
}

\author{
THE DIGNITY OF THE HUMAN PERSON AND THE WOMAN IN THE BRAZILIAN CARCER: \\ AN ANALYSIS FROM THE RIGHTS OF PERSONALITY
}

\section{Dirceu Pereira Siqueira}

\begin{abstract}
Coordenador e Professor Permanente do Programa de Doutorado e Mestrado em Direito do Centro Universitário Cesumar (UniCesumar); Pós-doutor em Direito pela Faculdade de Direito da Universidade de Coimbra (Portugal), Doutor e Mestre em Direito Constitucional pela Instituição Toledo de Ensino - ITE/Bauru, Especialista Lato Sensu em Direito Civil e Processual Civil pelo Centro Universitário de Rio Preto, Pesquisador Bolsista - Modalidade Produtividade em Pesquisa para Doutor - PPD - do Instituto Cesumar de Ciência, Tecnologia e Inovação (ICETI), Professor nos cursos de graduação em direito da Universidade de Araraquara (UNIARA) e do Centro Universitário Unifafibe (UNIFAFIBE), Professor Convidado do Programa de Mestrado University Missouri State - EUA, Editor da Revista Direitos Sociais e Políticas Públicas (Qualis B1), Consultor Jurídico, Parecerista, Advogado.

E-mail: dpsiqueira@uol.com.br.
\end{abstract}

\section{Sabrina Medina Andrecioli}

Mestra no Programa de Pós-Graduação em Ciências Jurídicas do Centro Universitário Cesumar de Maringá (UniCesumar), Especialista Lato Sensu em Direito Aplicado pela Escola da Magistratura do Paraná (Emap), Pósgraduanda em Docência no Ensino Superior: Tecnologias Educacionais e Inovação pelo Centro Universitário Cesumar de Maringá (UniCesumar); Professora de do Programa de Pós-graduação da UniCesumar e Unifatecie. Advogada em Maringá-PR. E.mail: sah_andri@ hotmail.com.

Recebido em: 26/09/2019

Aprovado em: 14/04/2020

RESUMO: A sociedade plurifacetada atual impõe ao Direito inovações em suas reflexões e respostas a temas que atingem a existência humana. Os direitos da personalidade é um direito subjetivo, que visa tutelar a própria pessoa humana, a sua dignidade e integridade. Diante de um quadro de enormes violações de direitos que a população carcerária feminina vivencia é que se verifica a real importância de se tratar da temática e dos direitos dessa população. Portanto, este trabalho tem por objetivo retratar as violações das mulheres presas e a questão da maternidade no cárcere, a partir do princípio da dignidade da pessoa humana como valor fundante de todo o sistema jurídico-social brasileiro. Após preocupou-se em dar maior visibilidade a situação de vulnerabilidade e sofrimento das mulheres presas, na ânsia de amenização da sensação de incertezas quanto ao futuro, através de implantação e implementação de políticas públicas específicas para tal realidade. Empregou-se para tanto o método de abordagem dedutivo, com o objetivo a formulação de uma linha do tempo, com a elaboração de um sistema estruturado no decorrer dos anos, comportamentos e mudanças valorativas, com o intuito de levantamento de hipóteses reflexivas sobre a temática do cárcere brasileiro e seus problemas, especificamente o encarceramento feminino e as violações de direitos sofridas pelas mulheres.

Palavras-Chave: Dignidade da Pessoa Humana. Direitos da Personalidade. Encarceramento Feminino. Filhos na Prisão. Mulheres. 


\begin{abstract}
The current multifaceted society imposes on the Law innovations in its reflections and responses to themes that affect human existence. The rights of the personality is a subjective right, which aims to protect the human person himself, his dignity and integrity. Faced with a scenario of enormous violations of rights that the female prison population experiences is that the real importance of dealing with the issue and the rights of this population is verified. Therefore, this work aims to portray the violations of women prisoners and their children born in prison, based on the principle of the dignity of the human person as a founding value of the entire Brazilian legalsocial system. Afterwards, she worried about giving greater visibility to the situation of vulnerability and suffering of women prisoners, in the eagerness to soften the sense of uncertainty about the future, through the implementation and implementation of public policies specific to this reality. The hypothetical-deductive method was used, and as a procedure method, the casuistic and the functional were used, as far as the methods of investigation were used bibliographical and documentary.
\end{abstract}

Keywords: Children in Prison. Dignity of the Human Person. Female Incarceration. Rights of the Personality. Women.

SUMÁRIO: Introdução; 1 Os Direitos da Personalidade, Concepção de Pessoa e Personalidade; 2 A Dignidade da Pessoa Humana e o Sistema Prisional Feminino; 3 A Invisibilidade das Mulheres em Situação de Cárcere e os Direitos da Personalidade; 4 Mães Em Situação De Cárcere; Considerações Finais; Referências.

\title{
INTRODUÇÃO
}

Diante de um cenário de invisibilidade, violência e descaso em que estão inseridas as mulheres em situação de cárcere, se traz à tona a importância de estudar a temática, o presente trabalho tem como finalidade promover reflexões sobre o sistema prisional feminino brasileiro. Para tanto, fixa o princípio da dignidade da pessoa humana como cláusula geral de proteção da pessoa, o que fundamenta a interligação dos direitos fundamentais e dos direitos da personalidade na ordem jurídica brasileira.

O princípio da dignidade da pessoa humana é o núcleo irradiador de todos os direitos fundamentais, alicerce do ordenamento jurídico que considera cada ser humano igual e possuidor do direito de desenvolver-se física e psiquicamente, com respeito à vida e à liberdade. Assim, diante desta perspectiva, tendo em vista o considerável aumento do número de prisioneiras no sistema penitenciário brasileiro e as violações de direitos fundamentais sofridas por esta população, é que se busca dar voz àquelas que são historicamente silenciadas em suas necessidades sociais, políticas e culturais.

Irá, por sua vez, detalhar e examinar o perfil da mulher presa no Brasil, desde escolaridade e classe social à tipo penal infringido. Essa análise evidenciará a seletividade penal existente no cárcere brasileiro, a imersão das mulheres no mercado das drogas e os desafios enfrentados para a reinserção desta população à sociedade. Porém, além dos desafios extramuros se buscará esmiuçar um desafio intramuros presente no cárcere feminino, o da maternidade (do período gestacional, parto e pós-parto), destacando a violência de gênero no contexto prisional, uma vez que não são atendidas as particularidades da mulher, especificamente no exercício da maternidade.

Utiliza-se o método de abordagem dedutivo, a partir de uma visão geral dos direitos da personalidade e da dignidade da pessoa humana como axioma justificante de todos os direitos fundamentais. Ou seja, se partirá de teorias, princípios e leis gerais para a ocorrência de fenômenos particulares, que no caso é o cárcere brasileiro e seus problemas, especificamente o encarceramento feminino e as violações de direitos sofridas neste ambiente. 
O emprego deste método possui como objetivo a formulação de uma linha do tempo, com a elaboração de um sistema estruturado no decorrer dos anos, comportamentos e mudanças valorativas, com o intuito de levantamento de hipóteses reflexivas sobre o tema. Já como método de procedimento, utiliza-se o histórico que consiste na descrição de acontecimentos históricos ocorridos bem como sua análise crítica, que no caso baseia-se na avaliação sobre o princípio da dignidade humana, perpassando sobre a concepção e definições de pessoa, personalidade e direitos da personalidade.

Além disso se utiliza do método estatístico ou quantitativo, onde se procura traçar o perfil da mulher presa por meio do levantamento penitenciário nacional. $\mathrm{E}$, quantos aos métodos de investigação, emprega-se o bibliográfico onde procura-se explicar o encarceramento feminino e a seletividade penal a partir de referenciais teóricos, de revisão de literatura de obras, artigos de periódicos e documentos eletrônicos oficiais.

Para tanto o estudo foi dividido em quatro tópicos. No primeiro, analisar-se-á o conceito de pessoa, de personalidade e, por fim, os direitos da personalidade no direito contemporâneo, demonstrando a evolução dessa matéria. Já no segundo tópico, far-se-á uma reflexão da Dignidade da Pessoa Humana como axioma justificante dos direitos fundamentais através de um breve discorrer histórico. Se iniciará, ainda neste tópico, a contextualização da situação carcerária feminina no Brasil e suas respectivas violações de direitos.

No terceiro momento investigar-se-á o fenômeno da invisibilidade das mulheres, em que se traçará o perfil da população carcerária feminina quanto ao regime, crime, nível de escolaridade e idade. E, por fim, o último tópico abordará a maternidade no cárcere, uma temática de extrema importância tanto no âmbito da realidade criminal do país, como no contexto social, pois visa analisar os desafios para acessar os direitos e garantias da presa gestante a qual se encontra cumprindo pena restritiva de liberdade. Se evidenciará o julgamento histórico proferido pela Segunda Turma do Supremo Tribunal Federal ao examinar o Habeas Corpus coletivo $\mathrm{n}^{\circ}$ 143.641/SP. O principal ponto de observação se refere às particularidades inerentes à mulher, especificidades essas que vão de uma estrutura carcerária inadequada até a má execução dos tratamentos especiais assegurados pela legislação para propiciar uma gravidez saudável e, após o nascimento, o convívio mãe-filho. Restando claro, portanto, a necessidade de perspectivas diferenciadas no tratamento da temática, calcadas nas vicissitudes de gênero.

\section{DIREITOS DA PERSONALIDADE, CONCEPÇÃO DE PESSOA E PERSONALIDADE}

Diante do aumento substancial da população carcerária feminina e do cenário de invisibilidade, violência, descaso e violações de direitos fundamentais que esta parcela vivencia é que se verifica a real importância de se tratar da temática mulheres em situação de cárcere. Para promover reflexões sobre o sistema prisional brasileiro e as consequências dos problemas do cárcere feminino, se faz mister, inicialmente, a compreensão sobre a dignidade da pessoa humana como sustentáculo de todo o ordenamento jurídico, a partir da concepção de pessoa, personalidade e dos direitos da personalidade, bem como suas características.

O Direito é concebido tendo como destinatário o próprio ser humano em convivência, por isso é importante para compreensão do fenômeno jurídico a ideia de pessoa e personalidade (CANTALI, 2009, p. 27). Assim, o Direito existe por causa do homem, se vislumbra a pessoa como protagonista do cenário jurídico, com a valoração da pessoa e a tutela dos direitos essenciais a ela. Orlando de Carvalho sintetiza esse cenário da seguinte forma: "Não da vida, mas da vida em relação, nasce o Direito, pelo que só ao nível das relações inter-humanas pode o Direito correctamente compreender-se" (CARVALHO, 1981, p. 45).

Extrair um conceito de pessoa de forma pura e descomplicada é uma tarefa difícil, principalmente quando examinada diante da diversidade jurídica-cultural. Existe um grande esvaziamento do conteúdo semântico da noção de pessoa, apesar de ser carregada de vários 
conteúdos jurídicos, filosóficos e políticos construídos ao longo do tempo (GONÇALVES, 2008, p. 19). Portanto, tendo em vista a existência de referenciais de validade para a construção do conceito de pessoa, tão importante no campo do direito, se fará uma breve reflexão sobre a evolução deste conceito.

Apesar da Antiguidade ter se aprofundado no que se refere a realidade humana, não houve estruturação de um conceito de pessoa como categoria ontológica, isso se deve ao fato de existir uma enorme dificuldade no pensamento antigo em lidar com as realidades individuais em face da visão monista da realidade (GONÇALVES, 2008, p. 23). Nesse período histórico, apesar de existir instrumentos de proteção da dignidade humana, deixava-se de considerar e valorizar individual e subjetivamente o próprio sujeito. O homem era concebido como parte integrante de um todo, a coletividade sobrepunha-se ao indivíduo.

A pólis emergia como elemento de maior importância, o que se verifica é "[...]a visão do homem como peça do cosmos, sacrificando a sua individualidade ante a razão da universalidade (GONÇALVES, 2008, p. 23-24). A onipotência do Estado, na concepção de Platão e também de Aristóteles, trazia, como consequência principal, a negação da própria dignidade humana e autonomia individual.

O conceito individual vai se desenvolvendo com o transcorrer do tempo, e é, principalmente, com o surgimento do cristianismo e da figura da Santíssima Trindade, que o conceito de pessoa se dota de conteúdo metafísico. O fundamento para tanto se centrou no postulado de Deus ter criado o homem à sua imagem e semelhança, razão pela qual à todos haveria de ser outorgado o mesmo respeito e deferência, ante a equivalência relativa entre o homem e Deus (SARLET, 2009).

Neste momento, a pessoa passa ser uma verdadeira categoria ontológica designando uma realidade substantiva. E, desta concepção de pessoa que sobressai o caráter único do ser humano, bem como a ideia de que todos os seres humanos são iguais em dignidade, verifica-se que todos são naturalmente dotados da mesma racionalidade (STANCIOLI, 2010).

No pensamento moderno o conceito de pessoa se modifica, foi um período marcado pela subjetividade do pensamento. No século XVIII os direitos tornam-se efetivamente os valores mais importantes da convivência humana em sociedade. Um dos expoentes desta época foi Immanuel Kant, para este a realidade pessoal está na consciência moral, o "eu" está no "dever ser", sendo impossível pensar a pessoa no sentido ôntico (GONÇALVES, 2008, p. 31). Nas formulações do filósofo prussiano se identifica uma nítida noção de pessoa, a existência dos seres não depende necessariamente da vontade, e sim da natureza. Portanto, os seres irracionais têm valor relativo, já os seres racionais são as pessoas, isto se deve:

[...] porque a natureza deles os designa já como fins em si mesmos, isto é, como alguma coisa que não pode ser usada unicamente como meio, alguma coisa que, consequentemente, põe um limite, em certo sentido, a todo livre arbítrio -e que é objeto de respeito- (KANT, 2011, p. 28).

O filósofo acreditava no caráter racional do ser humano, caráter que o diferencia de todas as outras coisas. Nesse sentido, os seres humanos são agentes livres capazes de tomar suas próprias decisões, estabelecer seus próprios objetivos e guiar suas condutas por meio da razão (RACHEL, 2006, p. 132). O homem é o único ser na natureza capaz de estabelecer um fim para si e, ao mesmo tempo, fazer da felicidade de outrem o seu próprio fim (KANT, 2012).

O homem, como ser racional, existe como fim em si e não é simplesmente meio. Assim, só o ser humano, sem distinção, é pessoa, ou seja, um ser que é ao mesmo tempo, fonte e imputação de todos os valores. A dignidade é atributo intrínseco da essência da pessoa humana, o único ser que compreende um valor interno, superior e que não admite substituição equivalente.

A Constituição brasileira, reconhecendo a existência e a eminência da dignidade da pessoa humana, a transformou num valor supremo da ordem jurídica quando a declara como um dos

Revista de Direito Brasileira | Florianópolis, SC | v. 24 | n. 9 | p.463-488 | Set./Dez. 2019 
fundamentos da República Federativa do Brasil, constituída em Estado Democrático de Direito ${ }^{1}$. Sendo, o valor de pessoa, enquanto conquista histórico-axiológica, encontra a sua expressão jurídica nos direitos fundamentais.

A variação e a constância na história do Direito são denominadas de constelações e invariantes axiológicas, as primeiras formam-se pelos comportamentos sociais em dado momento, são mutáveis. Por sua vez, as invariantes constituem a carga axiológica integrada ao próprio patrimônio ético da humanidade, cuja expressão sustenta-se na dignidade da pessoa humana (BITTAR; ALMEIDA, 2010). De acordo com Miguel Reale, o conteúdo transcendente e imutável capaz de legitimar a ordem positiva revela-se na figura do ser humano, o qual denomina de pessoa como valor-fonte, assim:

Penso eu que, se o homem, em dado momento de sua história, adquire consciência de seu próprio valor como pessoa, é sinal que nele havia a priori a condição de possibilidade da aquisição desse valor, o qual, uma vez adquirido, se apresenta como uma invariante axiológica. É à luz desse entendimento, que corresponde a um historicismo axiológico, que apresento a pessoa como valor-fonte do Direito (REALE, 1998, p. 62).

Logo, uma vez constatada a importância do ser humano pelo próprio sujeito, institui-se o objeto de constatação como elemento axiológico transcendental, sobre o qual se fundamenta a construção normativa. Foi por meio de uma extensa experiência social que se deu a emergência do valor da pessoa; mas, uma vez revelado esse valor, ele se tornou uma constante axiológica (REALE, 1998, p. 63).

Portanto, ao se verificar a condição da pessoa como valor-fonte, o que se justifica e fundamenta o sistema normativo, retrata a total renúncia de que tal condição seja afastada. (REALE, 1998). Mesmo, em razão de fatores históricos e sociais de um determinado momento, não seria cabível admitir a negativa do alto valor atribuído a pessoa humana. Assim, configura-se em uma pedra de toque essencial de aferição de legitimidade da ordem jurídica positiva.

De acordo com Comparato (2005), reagindo contra a crescente despersonalização do homem no mundo, como reflexo da mecanização e burocratização da vida em sociedade, a reflexão filosófica da primeira metade do século XX acentuou o caráter único, inigualável e irrepetível da pessoa individual. Assim, o pensamento filosófico do século XX colocou em foco a realidade essencialmente relacional da vida, implicada, de certa forma, no inter-relacionamento sujeito e objeto.

Portanto, o que seria efetivamente Pessoa? Compartilhando do entendimento de Gonçalves (2008, p. 64), pessoa é inegavelmente uma realidade ôntica, que envolve um aspecto relacional, sendo ainda necessário para o desenvolvimento, terceiro aspecto finalístico e ético do ser humano. A perspectiva atual de pessoa, coloca-a como âncora da noção de dignidade humana. Apenas a pessoa fornece a razão da dignidade, só ela nos permite apreender as próprias consequências da dignidade.

Dado o conceito atual de pessoa, é importante definir o que é personalidade e o que seria efetivamente os direitos da personalidade, para que assim se possa ter maior compreensão da magnitude das violações à dignidade ocorridas no cárcere brasileiro.

A personalidade pode ser definida como um atributo do ser humano que o acompanhará por toda a sua vida, se resume no complexo de caracteres do próprio indivíduo, consistindo na parte intrínseca da pessoa humana (SZANIAWSKI, 2005, p. 70). Ela é decorrente da própria projeção

\footnotetext{
${ }^{1}$ Art. $1^{\text {o }}$ A República Federativa do Brasil, formada pela união indissolúvel dos Estados e Municípios e do Distrito Federal, constitui-se em Estado Democrático de Direito e tem como fundamentos: [...] III - a dignidade da pessoa humana; [...]. Disponível em: http://www.planalto.gov.br/ccivil_03/Constituicao/Constituicao.htm. Acesso: 10 Jun 2019.
} 
da natureza humana conforme a visão kantiana, ou seja, é a condição humana que determinará que o indivíduo é detentor de personalidade.

Nesse sentido, vale lembrar que atualmente houve uma mudança da concepção de personalidade jurídica como um conceito meramente simplório e coincidente com a noção de capacidade jurídica, passando a ser compreendida como um valor jurídico ou princípio. Autores civilistas como San Tiago Dantas e Carlos Alberto da Mota Pinto vinculam a noção de personalidade jurídica à ideia de dignidade da pessoa humana, que se valoriza com o reconhecimento de um círculo de direitos de personalidade (BORGES, 2009, p. 12-13).

Carl Gustav Jung trabalha com o desenvolvimento da personalidade, definindo esta como:

[...] a realização máxima da índole inata e específica de um ser vivo em particular. Personalidade é a obra a que se chega pela máxima coragem de viver, pela afirmação absoluta do ser individual, e pela adaptação, a mais perfeita possível, a tudo que existe de universal, e tudo isto aliado à máxima liberdade de decisão própria (JUNG, 2006, p. 177).

Jung teoriza a ideia da educação para a personalidade, que se dá por meio de três formas: educação pelo exemplo; a educação coletiva ou consciente e por meio da educação individual (JUNG, 2006, p. 161). A primeira forma ocorre espontaneamente e de modo inconsciente, sendo a forma mais antiga e mais eficaz, tendo em vista a identificação da criança com os pais, do ponto de vista psicológico. A segunda forma consiste na educação segundo regras, princípios e métodos, é de natureza coletiva por serem válidos e aplicáveis para certo número de indivíduos, e produz aquilo que está contido nas premissas, gerando uma uniformidade.

$\mathrm{O}$ autor adverte que apesar de ser indubitavelmente útil, essa forma de educação pode trazer danos gravíssimos para a índole individual, trazendo à tona a insegurança na tomada de decisões individuais. E por fim, a terceira forma de educação, a individual, pretende desenvolver a índole específica do indivíduo, deixando as regras e métodos em segundo plano, quando houver resistência à educação coletiva, será destinada àqueles que apresentam uma singularidade individual ou não têm facilidade de adaptação.

Nesse contexto, na educação para a personalidade, a família e o pedagogo são de grande importância para o desenvolvimento do indivíduo. Uma educação acessível e de qualidade, uma estrutura familiar que dê suporte às peculiaridades do desenvolvimento da criança e do jovem, são essenciais para a evolução da pessoa e, por conseguinte da própria sociedade.

Ainda, quanto a personalidade, Espínola leciona que ela é o pressuposto de todo o direito, sendo assim é:

[...] o elemento que atravessa todos os direitos privados e que em cada um deles se contém; não é mais que a capacidade jurídica, a possibilidade de ter direitos. Todo homem, por necessidade de sua própria natureza, é o centro de uma esfera jurídica e assim tem personalidade, é pessoa (ESPÍNOLA, 1977, p. 323).

Assim, a pessoa humana traz em si valores que lhe são privativos, e esses valores integram a sua personalidade e lhes dão o potencial de desenvolver-se em sociedade. Os Direitos de Personalidade surgem da importância da proteção da pessoa e de sua personalidade.

Para Elimar Szaniawski (2005, p. 241), direitos de personalidade pertencem à categoria especial dos direitos subjetivos, e se enquadram no conceito de direito natural por se apoiarem na natureza das coisas. Ainda, esses direitos são inerentes à pessoa, por se tratar de diversos aspectos da manifestação da personalidade humana, não cabendo, assim, a divisão entre direito público e privado.

É essencial a compreensão de que por meio dos direitos da personalidade, o ser humano tem tutelado pelo Direito o respeito e a garantia a todas as expressões e potencialidades da 
personalidade humana (FERMENTÃO, 2006), o que abrange toda a esfera individual, acrescentando-lhe o respeito a valores como a vontade, a igualdade, a segurança e o desenvolvimento da personalidade. Nesse sentido, Francisco Amaral leciona:

Os direitos da personalidade, como direitos subjetivos, conferem ao seu titular o poder de agir na defesa dos bens ou valores essenciais da personalidade, que compreendem, no seu aspecto físico o direito à vida e ao próprio corpo, no aspecto intelectual o direito à liberdade de pensamento, direito de autor e de inventor, e no aspecto moral o direito à liberdade, à honra, ao recato, ao segredo, à imagem, à identidade e ainda, o direito de exigir de terceiros o respeito a esses direitos (AMARAL, 2000, p. 246).

A conceituação trazida por Cantali (2009, p. 28) examina os direitos da personalidade como os direitos atinentes à tutela da pessoa humana, os quais são considerados essenciais diante da necessária proteção da dignidade da pessoa humana e da sua integridade psicofísica. Se compactua com o entendimento de que a Constituição brasileira de 1988 ao expressamente consagrar no artigo $1^{\circ}$, incisos II e III, o princípio sede da dignidade da pessoa humana e da cidadania como fundamento da nação brasileira, se edifica em uma verdadeira cláusula geral de proteção da personalidade humana (SZANIAWSKI, 2005, p. 120).

Certifica-se, ainda, que o artigo $5^{\circ}, \S 2^{\circ}$ da Constituição inclui os direitos e garantias fundamentais oriundos de tratados internacionais em que o Brasil faz parte, exemplos importantes são a Declaração Universal dos Direitos do Homem e do Cidadão e o Pacto de São José da Costa Rica de 1969. Deste modo, os princípios constitucionais fundamentais tendo como axioma justificante o princípio da dignidade da pessoa humana, juntamente com os princípios internacionais oriundos de tratados, forma um conjunto de sustentação do direito geral da personalidade brasileiro, e também informam os direitos especiais de personalidade.

Os direitos de personalidade reconhecidos, ou não, como direitos inatos, se constituem em direitos mínimos que visam assegurar e resguardar a dignidade da pessoa humana e como tais devem estar previstos e sancionados pelo ordenamento jurídico (FREITAS; MOTTA, 2015, p. 54). Se reconhece, portanto, um direito geral de personalidade, a que se remeteriam todos os outros tipos de direitos previstos, ou não, no sistema jurídico.

Após análise dos conceitos trazidos, fica nítida a magnitude da importância dos direitos da personalidade e sua proteção pelo ordenamento jurídico, nacional e internacional. Se denota a relevância do princípio da dignidade da pessoa humana para preservação o Estado Democrático de Direito. Neste contexto, passa-se a analisar a Dignidade da Pessoa Humana como axioma justificante dos direitos da personalidade, dando enfoque nas violações ocorridas no cenário prisional brasileiro, principalmente com relação a situação das mulheres encarceradas.

\section{A DIGNIDADE DA PESSOA HUMANA E O SISTEMA PRISIONAL FEMININO}

O objetivo desse estudo é promover a reflexão acerca da dignidade da pessoa humana prevista de forma expressa na Constituição brasileira de 1988 como núcleo fundante de todo o ordenamento jurídico. Apesar, da Constituição Federal garantir a dignidade humana como paradigma jurídico perfeito, o paradigma social vivencia-se um drama que configura um cenário oposto do esperado. Quando examinado o sistema carcerário os problemas se avultam ainda mais, o distanciamento entre a vontade da lei e a realidade do sistema carcerário nacional é acentuado e decorre da falta de vontade política do Estado em tutelar uma minoria impopular.

Ao exercer concretamente a punibilidade, o Estado tem cerceado não só a liberdade do cidadão, mas também outros direitos fundamentais não abrangidos pela sentença, dentre eles encontra-se violações da honra, da privacidade, da intimidade, da liberdade sexual, da saúde, da 
Educação, da assistência jurídica e outros. Vivencia-se um sistema longe de servir de instrumento de ressocialização, é uma parcela do invisível para o Estado.

Portanto o presente tópico visa analisar mais especificamente o princípio da dignidade da pessoa humana como base dos direitos fundamentais, bem como a tutela destes direitos no âmbito carcerário feminino, tendo em vista que, a violência, a invisibilidade e o abandono são levados ao extremo dentro do estigmatizante sistema de justiça criminal.

O princípio da dignidade da pessoa humana constitui núcleo fundante e essencial de todos os direitos fundamentais previstos na ordem constitucional, e considera cada ser humano igual e possuidor do direito de desenvolver-se física e psiquicamente, com respeito à vida e à liberdade. Nessa perspectiva, a dignidade da pessoa humana encontra-se no cerne da ordem jurídica brasileira concebendo a valorização da pessoa humana como sendo razão fundamental para a estrutura de organização do Estado (FERMENTÃO, 2016. p. 892).

Os primórdios da ideia de dignidade da pessoa humana, como valor intrínseco a todo o ser humano, já podiam ser observados no pensamento clássico e no ideário cristão. No cenário cristão, isso se evidencia na afirmação do Papa Leão Magno de que os seres humanos seriam dotados de dignidade por terem sido criados à imagem e semelhança de Deus, posição também defendida por Tomás de Aquino, mas que acrescenta o fato da autodeterminação (SARLET, 2009, p. 32).

São Tomás de Aquino, pertencente a corrente filosófica da escolástica, utiliza a expressão dignitas humanas em sua obra Suma teológica, ele ressalta capacidade de autodeterminação inerente à natureza humana, seu pensamento não foi influenciado somente pela doutrina judaicocristã, mas também pela filosofia estoica (AQUINO, 2001, p. 411).

A razão e a capacidade intelectual são os caracteres distintivos do ser humano, e é no pensamento de Tomás de Aquino que restou afirmada a noção de que a dignidade encontra seu fundamento na circunstância de que o ser humano foi feito à imagem e semelhança de Deus, e que por força de sua dignidade, o ser humano, sendo livre por natureza, existe em função da sua própria vontade.

Em conformidade com o pensamento jusnaturalista dos séculos XVII e XVIII, ou seja, durante o trânsito da Renascença para a Ilustração, verificou-se um profundo processo de desmistificação da compreensão dos fenômenos humanos e de substituição das fontes heterônomas tradicionais. Nesse período histórico operou-se uma perda significativa do protagonismo político e institucional da Igreja Católica. É nesta nova conjuntura que a concepção da dignidade da pessoa humana passou por um processo de racionalização, que manteve a ideia de igualdade entre todos os homens em dignidade. Sarlet (2009, p. 35) destaca a importância de Samuel Pufendorf neste período, este foi o pioneiro no desenvolvimento de uma fórmula mais ampla e puramente secular e racional da noção de dignidade da pessoa humana; marcando, assim, uma clara ruptura com a tradição teológica de raízes medievais.

Foi, todavia, com Immanuel Kant com sua filosofia iluminista inspirada na antropologia de Rousseau, que o processo de secularização da noção de dignidade consolidou-se de vez por todas; a concepção de dignidade humana para Kant parte da autonomia ética como fundamento da dignidade (SARLET, 2009, p. 35-37), se resumindo no fato do homem existir como um fim em si mesmo, a dignidade independe de qualquer condição. Apresenta desta forma um conceito inicial de dignidade:

No reino dos fins tudo tem ou um preço ou uma dignidade. Quando uma coisa tem um preço, pode-se pôr em vez dela qualquer outra como equivalente; mas quando uma coisa está acima de todo preço, e, portanto, não permite equivalente, então tem ela dignidade (KANT, 2011, p. 77). 
Pode-se constatar que nesse conceito Kant afirma que a dignidade não pode ser valorada, sendo a racionalidade o meio pelo qual o ser humano terá total liberdade sob suas ações, alcançando, assim, sua dignidade.

A dignidade humana pode, ainda, ser compreendida sob duas dimensões: A primeira dimensão básica, na qual está a teoria Kantiana, em que se encontram os bens jurídicos básicos e essenciais para a existência humana, os quais são necessários para o exercício da autodeterminação de cada indivíduo, impedindo a sua coisificação; e a segunda dimensão cultural em que se tem importância os valores que variam no tempo e no espaço, os quais buscam atender as demandas sociais da época, em cada sociedade, de acordo com as suas possibilidades econômicas, políticas e culturais.

A dimensão básica da dignidade humana representa, conforme Sarlet (2009, p. 49-51), uma qualidade própria do indivíduo que vai demandar o respeito por sua vida, liberdade e integridade física e moral materializando-se em um conjunto de direitos elementares que impedem a coisificação do ser humano a violação desta dimensão da dignidade humana é facilmente constatada, já que estará caracterizada em qualquer situação em que uma pessoa venha a sofrer a redução de seu status como sujeito de direitos, para o de mero instrumento ou coisa, deixando de ser um fim em si mesmo.

A dimensão cultural da dignidade humana, por sua vez, representa as formas e as condições de como a dignidade humana, em sua dimensão básica, é implementada por cada grupo social ao longo da história, franqueando espaço para as peculiaridades culturais e suas práticas, variáveis no tempo e no espaço, pois se busca uma compreensão ética das finalidades de cada grupo social, a fim de se construírem significados que tenham a capacidade de serem entendidos interculturalmente (HOFFE, 2005, p. 77-78).

A dupla dimensão da dignidade humana, permite compreendê-la como limite e como tarefa do Estado e da própria sociedade. Limite por tratar-se de atributo que protege o indivíduo contra qualquer forma de coisificação, opondo-se, inclusive, contra práticas culturais que impliquem na redução da pessoa, "deve ser compreendida dentro de uma concepção absoluta, como regra, não ponderável. " Tarefa por exigir dos órgãos Estatais e da coletividade prestações positivas de promoção e proteção, dimensão em que "o conceito da dignidade é relativo, pois ela assume morfologicamente a função de princípio, admitindo ponderação quando em colisão com outros direitos" (MORAES, 2003, p. 116-118).

Diversas formulações ideológicas tomaram curso fortemente inspiradas nos postulados filosóficos kantianos, como exemplos são: o liberalismo clássico, socialismo, marxismo, o liberalismo moderno, entre outros. $\mathrm{O}$ fato é que, ao chegar ao século $\mathrm{XX}$, após inúmeras atrocidades e experiências históricas de aniquilação do ser humano vividas na história, como a inquisição, a escravatura, o nazismo e os genocídios étnicos, tornou-se necessário o reconhecimento da Dignidade da Pessoa Humana como uma conquista de razão ético-jurídica. Conforme aduz Comparato:

[...]A cada grande surto de violência, os homens recuam, horrorizados, à vista da ignomínia que afinal se abre claramente diante de seus olhos; e o remorso pelas torturas, as mutilações em massa, os massacres coletivos e as explorações aviltantes fazem nascer nas consciências, agora purificadas, a exigência de novas regras de uma vida mais digna para todos (COMPARATO, 2014, p. 50).

Houve uma reaproximação do direito da moral e da filosofia política, com a ascensão de uma cultura jurídica pós-positivista. A dignidade desempenha um grande papel nessa teoria jurídica repaginada, no qual a interpretação da norma é marcantemente motivada por valores éticos e fatos sociais (BARROSO, 2013, p. 18). Nessa esteira, diante da reconstrução do mundo moralmente devastado pelo totalitarismo e pelo genocídio Luís Roberto Barroso aduz: 
[...] A dignidade humana foi incorporada ao discurso político dos vitoriosos como uma das bases para uma longa e aguardada era de paz, democracia e proteção dos direitos humanos. A dignidade humana foi então importada para o discurso jurídico devido a dois fatores principais. O primeiro deles foi a inclusão em diferentes tratados e documentos internacionais, bem como em diversas constituições nacionais, de referências textuais à dignidade humana. $\mathrm{O}$ segundo fator corresponde a um fenômeno mais sutil, que se tornou mais visível com o passar do tempo: a ascensão de uma cultura jurídica, pós-positivista, que reaproximou o direito da moral e da filosofia política, atenuando a separação radical imposta pelo positivismo pré-Segunda Guerra (BARROSO, 2013, p. 1819).

A Declaração Universal dos Direitos Humanos de 1948 objetivou delinear uma ordem pública fundada no respeito à dignidade humana, ao consagrar valores básicos universais consagrou a dignidade da pessoa. Deste modo, a dignidade humana se tornou o valor fundante do sistema dos direitos fundamentais e se converteu no patrimônio jurídico-moral da pessoa humana estampada nos direitos subjetivos incorporados e assegurados pelo sistema constitucional.

Nessa esteira, a dignidade da pessoa humana é um princípio fundamental que inspiram a ordem jurídica, uma vez que possui natureza de valor supremo que dimensiona e humaniza a pessoa para realização e a efetivação dos direitos fundamentais (SILVA, 2000). Assim, a dignidade humana encontra-se no cerne da ordem jurídica brasileira concebendo a valorização da pessoa humana como sendo razão fundamental para a estrutura de organização do Estado. Considera-se que cada ser humano é igual e possuidor de direitos, independente da circunstância em que nasceu, de sua opção sexual, de sua cultura, religião e governo, pois só depende de sua existência.

Então, o princípio da dignidade no direito atual passa a servir como fundamento da universalidade dos direitos humanos, sendo um princípio jurídico unificador de todo o sistema normativo. Sarlet (2009), assim como outros autores, concebe a existência de uma dignidade comum a todos os seres humanos, fomentada no respeito e na satisfação de uma série de direitos indispensáveis para a garantia de uma vida digna, o que, consequentemente, justificaria a universalização dos direitos fundamentais.

Desta feita, a Constituição Brasileira de 1988 é um espelho da metamorfose paradigmática da lente ex parte principis para a ex parte populi, ou seja, não é mais sob a perspectiva do Estado que se afirmam o direito, e sim sob a perspectiva dos direitos que se afirma o Estado (PIOVESAN, 2013, p. 96). A dignidade da pessoa humana é a norma irradiadora e que instrui o constitucionalismo contemporâneo. Bonavides leciona que a força normativa deste princípio fundamental e sua densidade jurídica deve ser máxima, o princípio em que " [...] todos os ângulos éticos da personalidade se acham consubstanciados” (BONAVIDES, 2001, p. 233).

Os direitos da personalidade, então, encontram fundamento de orientação no princípio da dignidade da pessoa humana. São direitos pertencentes à tutela da pessoa humana, os quais são essenciais diante da necessária proteção da dignidade da pessoa humana e da sua integridade psicofísica (CANTALI, 2009, p. 28). Assim, só será possível perceber todos os aspectos da personalidade, se efetivamente houver o reconhecimento da dignidade.

Acerca da magnitude da tutela dos direitos da personalidade, enfatiza-se a necessidade de ser orientada por princípios constitucionais privilegiando a dignidade da pessoa humana e o livre desenvolvimento da personalidade (CANTALI, 2009, p. 53). Importa destacar que a dignidade humana pode ser ofendida de diversas formas, Celso Ribeiro Bastos e Ives Gandra Martins lecionam que ela pode ser desrespeitada:

Tanto a qualidade de vida desumana quanto a prática de medidas como a tortura, sob todas as suas modalidades, podem impedir que o ser humano cumpra na terra a sua missão, conferindo-lhe sentido. Esta é uma tarefa eminentemente pessoal. O 
sentido da vida humana é algo forjado pelos homens. O Estado só pode facilitar essa tarefa na medida em que amplie as possibilidades existenciais do exercício da liberdade (BASTOS; MARTINS, 1988, p. 425).

O princípio da dignidade da pessoa humana demarca um campo de padrão mínimo na esfera dos direitos sociais, e isso evidencia que a falta de condições materiais mínimas ao homem retira da pessoa o seu desenvolvimento físico e psíquico, gerando a injustiça. Portanto as agressões contra a dignidade atentam contra a própria humanidade do indivíduo, e cabe ao Estado proteger ativamente a vida humana, não somente coibir, ou seja, é própria razão de ser do Estado. Desse modo é que se verifica a magnitude da eficácia do Princípio da dignidade humana para a justiça (FERMENTÃO, 2016).

É nessa direção que se enquadra a temática do encarceramento brasileiro, diante de um cenário de invisibilidade, violência e descaso dos homens e mulheres presos que se verifica a situação nacional de fragilidades das políticas criminais e sociais no que concerne à redução das desigualdades e ao fortalecimento da cidadania dessas pessoas e de suas famílias.

O Brasil carece de interesse político em envolver uma minoria lamentavelmente invisível aos olhos da sociedade e, especialmente, do Parlamento. As políticas públicas relacionadas ao cárcere não são populares e dificilmente encontram respaldo dos congressistas. Além do mais, vivencia-se uma cultura punitiva diante do quadro da violação constante a direitos fundamentais e falência de políticas públicas, a usual expressão "bandido bom é bandido morto", define a mentalidade de grande parte da população, é mais fácil crer nisso do que reconhecer parcela culpa da própria sociedade pela deterioração do tecido social (SANTOS; ÁVILA, 2017, p. 273-274).

$\mathrm{O}$ atual sistema prisional brasileiro parece desconhecer ou desprestigiar os princípios basilares da Constituição, o quadro indica violação do princípio da dignidade da pessoa humana, da proibição da tortura, do tratamento desumano ou degradante e das sanções cruéis, do cumprimento da pena em estabelecimentos distintos, de acordo com a natureza do delito, a idade e sexo do apenado, do respeito à integridade física e moral dos presos, da presunção de não culpabilidade, dos direitos fundamentais à saúde, à educação, à alimentação apropriada e do acesso à Justiça.

O total desrespeito dos direitos fundamentais é revelado de forma inequívoca no retrato brasileiro do cárcere, e esta realidade é consideravelmente intensificada nas prisões de mulheres. As necessidades e experiências femininas devem ser reconhecidas de acordo com o universo feminino e não simplesmente adaptada aos moldes masculinos (MENDES, 2017, p. 215).

Assim, para uma melhor compreensão da temática, é de grande importância explorar cenário atual do sistema prisional brasileiro feminino, visto que é o enfoque deste estudo, e isto é o que se fará no próximo tópico.

\section{A INVISIBILIDADE DAS MULHERES EM SITUAÇÃO DE CÁRCERE E OS DIREITOS DA PERSONALIDADE}

Importante reforçar que o Brasil possui como cláusula geral de proteção de direitos calcada na Dignidade da Pessoa Humana. Apesar da Constituição Federal brasileira não possuir expressamente uma disposição específica destinada a tutelar a personalidade humana, existe o reconhecimento do direito geral de personalidade através do princípio da dignidade da pessoa.

De acordo com Elimar Szaniawski (2005, p. 137), o princípio da dignidade da pessoa humana consiste em uma "cláusula geral de concreção da proteção e do desenvolvimento do indivíduo". Isso ocorre, em virtude da característica de princípio fundamental diretor que a dignidade possui, segundo o qual deve ser interpretado todo o ordenamento jurídico brasileiro.

A dignidade é ínsita ao ser que a tem mesmo antes de sua personalidade jurídica e a tem mesmo antes da organização jurídica existir. Neste sentido, Sampaio (2000, p. 30) leciona que a 
existência e eficácia da dignidade prescinde de legitimação, mediante reconhecimento expresso pelo ordenamento jurídico, assim, sob o ponto de vista jurídico, a dignidade tem sido definida como um atributo da pessoa humana, o "fundamento do primeiro e a finalidade última, de toda a atuação estatal e mesmo particular", o núcleo fundante dos direitos humanos e fundamentais.

A Constituição brasileira de 1988 seguiu a tendência de grande parte dos países ocidentais do pós-guerra e abrangia, como forma de reconsiderar a pessoa e reforçar a preocupação com ela, a dignidade e princípios derivados como núcleo de todo o ordenamento jurídico (LUISI, 2003, p. 11). Resumidamente, a Constituição Cidadã trouxe em seu texto diversos princípios e valores e princípios por meio dos quais se instaurou uma nova ordem jurídica que impôs um repensar de todo o sistema, na medida que o ser humano passou a ocupar o centro referencial do ordenamento, tendo em vista a eleição da dignidade humana como fundamento do próprio Estado Democrático de Direito (CANTALI, 2009, p. 84).

Já no preâmbulo e nos primeiros dois artigos da Constituição se verifica o balizamento de um Estado garantidor dos direitos individuais e sociais, com fundamento na própria dignidade humana e visando a construção de uma sociedade justa, pautada na solidariedade, liberdade e igualdade, tendo em vista que o fim último é a tutela da pessoa humana em todos os aspectos da vida. Neste sentido, Cantali (2009, p. 85-86) informa:

A proteção primordial da pessoa apenas enquanto ser dotado de dignidade impôs uma verdadeira alteração paradigmática, a partir da qual não mais se admite relegar ao segundo plano a tutela dos interesses existenciais posto que a dignidade humana, enquanto valor constitucional, é princípio fundamental do Estado Democrático de Direito, devendo ser o telos de todo o sistema. A dignidade da pessoa humana é valor fundante que serve de alicerce à ordem jurídica democrática. Tal assertiva indica o valor da dignidade humana alcança todos os setores da ordem jurídica, fato que traz em si a dificuldade de se estabelecerem os limites e o alcance de tal princípio. Na busca destes limites, necessário foi um retorno aos postulados filosóficos que nortearam o conceito de dignidade como valor intrínseco às pessoas humanas.

Com isso, é quase que automática a compreensão que todas as demais normas, incluindo as reguladoras de direitos da personalidade, devem se sujeitar à dignidade da pessoa humana para sua aferição de conformidade axiológica. Outrossim, a dignidade humana deve ser considerada como o centro da personalidade humana, merecendo larga proteção normativa. De acordo com Cortiano (1999, p. 42), é indissolúvel a ligação entre personalidade e dignidade humana, sendo que a proteção à personalidade se refere diretamente à proteção da dignidade do homem.

A Constituição Federal ao consagrar, já no artigo primeiro, a dignidade da pessoa humana, trouxe consigo todos os atributos inerentes à personalidade humana, da mesma forma que tutela no caput e nos incisos do artigo $5^{\circ}$ vários direitos da personalidade como a igualdade, liberdade, integridade psicofísica e a vida. Deve-se reforçar que esse rol não é taxativo, conforme Szaniawski (2005, p. 137-144), o constituinte especializou no artigo quinto, alguns direitos da personalidade humana, por intermédio das garantias fundamentais expressas na Constituição, neste sentido, o ordenamento jurídico brasileiro adotou um sistema de proteção misto no tocante à tutela da pessoa humana, traz um sistema geral de proteção de personalidade extraído diretamente do princípio da dignidade humana e, ao lado, protege alguns direitos especiais de personalidade tipificados como direitos fundamentais, os quais convivem harmonicamente, cuja finalidade é proporcionar o livre desenvolvimento da personalidade.

Disto isto, emerge o entendimento da dignidade como centro do ordenamento jurídico, sendo assim, fonte irradiadora dos direitos da personalidade. $\mathrm{O}$ ser humano adquire estes direitos pelo simples fato de nascerem, são, portanto, originários que decorrem exclusivamente do 
reconhecimento da personalidade jurídica, ou seja, sucedem da personalidade ontológica (CANTALI, 2009, p. 130-131).

Visto isso, depois de se tratar sobre tutela geral dos direitos da personalidade e suas características, passamos a constatar que a dignidade existe a todos os seres humanos, não pode ser retirada ou aparadas de qualquer forma, isso se transmite as suas demais emanações como os direitos da personalidade. Estes direitos são perenes a todos indistintamente, não importando se o indivíduo tenha cometido atos contrários às normas penais em vigor na sociedade. Neste ínterim Motta e Kloch (2008, p. 67) lecionam sobre a dificuldade em exercer discernimento e separar o homem que pratica o crime da criminalidade no geral.

No cárcere se denota uma violação massiva e sistemática dos direitos mais básicos do ser humano, os direitos fundamentais e da personalidade, mesmo havendo todo um aparato de proteção e tutela na Constituição, em leis infraconstitucionais e Tratados Internacionais em que o Brasil é signatário. No espaço prisional não se vê a dignidade e tão pouco a integridade moral respeitada. No encarceramento feminino se verifica a existência de peculiaridades do gênero, sendo necessário que haja plena compreensão das diferenças entre homens e mulheres para que se possa repensar a execução penal sem que haja excesso de execução no tocante às agressões aos direitos da personalidade das mulheres. As diversidades corporais, hormonais e emocionais devem ser consideradas, é necessário se observar o ser sem a dicotomia corpo e mente (BUGLIONE, 2007, p. 139-147).

O cárcere é palco de grandes violações e violências exercidas na execução penal. As consequências são notórias, essas agressões tidas como ação estatal de controle social e gerenciamento punitivo causam efeitos negativos nos indivíduos em direitos da personalidade como integridade psicofísica e moral, honra, dignidade sexual, imagem, entre outros. No encarceramento feminino, além dos já tratados, existe um plus na carga lesiva no cerceamento de direitos, segundo Pat Carlen (1990, p. 3) o "estigma e a invisibilidade" desta problemática decorre do fato de que dentre outras razões, as mulheres que são enviadas para a prisão têm sido tradicionalmente vistas como "duplamente desviadas", ou seja, não só são más cidadãs (visto que violaram a lei), mas sim, também como "mulheres não naturais" que infringiram os papéis tradicional e institucionalmente a elas destinados. De acordo com a autora, as mulheres encarceradas são enviadas para a prisão por delitos menos graves que os homens e em geral é provável que sejam mais pobres e que tenham saúde pior, além de que em vários casos terem sofrido muito mais como vítimas de abuso sexual e de violência.

As mulheres têm que se adaptar de modo forçado a um universo completamente masculino que é o penitenciário. As diferenças vigem no âmbito biológico (gravidez, menstruação, menopausa) e no cultural, as mulheres são as principais cuidadoras de crianças, os entornos sociais das mulheres são muitas vezes deprimidos, as mulheres que entram no cárcere geralmente sofrem mais violência, inclusive sexual, em muitos lugares é exigido normas comportamentais e inclusive de vestimenta; os estereótipos de gênero das mulheres estão mais presentes na prisão em relação aos regimes dos homens e com maior rigor disciplinar.

Visto isso, verifica-se a imprescindibilidade de uma adequação da vida carcerária às especificidades e necessidades das mulheres presas. Os atentados aos direitos destas mulheres em situação de cárcere surgem em razão de vários motivos, dentre os mais importantes, destaca-se o estrutural, o jurídico e o histórico-social. O primeiro refere-se à situação estrutural das prisões femininas brasileiras, nestes espaços se verifica uma enorme carência de vários serviços básicos que estão previstos no ordenamento interno e externo, um exemplo é quanto a quantidade de pessoas superiores ao aconselhável, em muitas situações ocorre a violação literal do artigo 40 e 88 da Lei de Execuções Penais.

Os direitos da personalidade diante da precariedade da estrutura que recebe mulheres em situação de cárcere, são claramente violados de forma flagrante, pois ocorre a transgressão à integridade psicofísica, à saúde, à higiene básica dentre outros. A higiene básica, por exemplo, é 
fundamental ao bem-estar da mulher encarcerada, à saúde e, inclusive, a autoestima. Muitas destas mulheres não recebem do Estado produtos essenciais para a higiene, como papel higiênico, pasta dental, absorventes. A saúde das aprisionadas fica em jogo diante da ausência de material adequado de higiene, umidade e falta de circulação de ar nas celas, tendo em vista que tudo isso corrobora para o aparecimento de doenças.

Várias situações que ocorrem na execução penal que estão ligadas à imagem tem efeitos sobre os direitos da personalidade, em particular a imagem e a integridade moral. Um ponto importante na autoimagem do encarcerado provem da estética, que é reforçada pela higiene básica, alimentação e saúde.

Além do defeito estrutural, outro motivo violador de direitos da personalidade é quanto as deficiências jurídicas. Estas falhas levam ao impedimento da consecução da plena tutela por ausência de mecanismos aptos a proteger a cidadão presa. O não respeito do artigo 89 da Lei de Execução Penal é um caso de deficiência jurídica grave. Este artigo trata da disposição legislativa referente a obrigação de existência de berçários, creches e seções de saúde gestacional.

Os dados trazidos pelo INFOPEN demonstram a precariedade que se é tratada a situação da maternidade no cárcere, é um grande exemplo de como o encarceramento feminino é calcado em diretrizes masculinizantes e de improviso. Somente $14 \%$ das unidades femininas ou mistas contam com berçário e/ou centro de referência materno-infantil, e apenas 3\% das unidades prisionais brasileiras declararam contar com espaço de creche, somando uma capacidade total para receber até 72 crianças acima de 2 anos (BRASIL, 2017b).

Com o aumento alarmante da população carcerária feminina, resta evidente a necessidade da reflexão sobre as causas e consequências de maneira que se valorize e se exponham as vicissitudes de gênero envolvidas. Os dados trazidos pelo Infopen, demonstra que o número de pessoas presas cresceu $707 \%$ em relação ao total registrado no início da década de 90 (BRASIL, 2017a), já com relação a população carcerária feminina o aumento exponencial chega à $656 \%$ em relação ao total registrado no início dos anos 2000, enquanto a masculina o porcentual foi de $293 \%$ no mesmo período (BRASIL, 2017b).

Apesar do grande aumento do percentual da população feminina no sistema prisional brasileiro, ainda se verifica um número de mulheres presas bastante inferior ao de homens. Fato utilizado para justificar a secundarização das necessidades específicas e para a quase inexistência política penitenciária que atenda o gênero feminino. Segundo Infopen, cerca de $74 \%$ das unidades prisionais destinam-se aos homens, $7 \%$ ao público feminino e outros $17 \%$ são caracterizados como mistos (BRASIL, 2017a).

Foi disponibilizado, recentemente, pelo Conselho Nacional de Justiça, acesso público aos dados do cadastro de grávidas e lactantes presas por Unidade da Federação. O Cadastro Nacional de informações referente às mulheres submetidas ao sistema prisional brasileiro foi determinação da presidente do órgão, ministra Cármen Lúcia (BRASIL, 2018). Diante da realidade brasileira das penitenciárias femininas, a iniciativa do $\mathrm{CNJ}$ é de grande importância. As informações do Cadastro vão conferir maior transparência e acompanhamento por parte Judiciário em relação a situação de mulheres presas e seus filhos.

De acordo com os levantamentos feitos pelo Infopen Mulheres 2017, denota-se, quanto ao regime de cumprimento de pena, que a maioria das presas se encontram presas no regime fechado (32\%). No regime semiaberto a porcentagem atinge $16 \%$, e no regime aberto estão $7 \%$. O que se denota do estudo é a assustadora porcentagem de $45 \%$ que se referem a população carcerária feminina presa provisoriamente, um aumento com relação a primeira edição do Infopen mulheres de junho de 2014, que apontava que 30,1\% nessa condição (BRASIL, 2017b).

A maior parte das mulheres presas no Brasil tem relação com o tráfico de drogas (62\%), 3 em cada 5 mulheres do sistema prisional, respondem por crimes ligados ao tráfico (BRASIL, 2017b). Embora o crime de tráfico seja expressivo na comunidade carcerária masculina, existe uma 
expressiva diferença quando tal estatística é confrontada com os dados referentes às penitenciárias femininas.

Outra faceta do perfil das mulheres encarceradas no Brasil diz respeito a educação, cor e nível social; de acordo com os levantamentos mais recentes do Ministério da Justiça e Segurança Pública, a maioria das mulheres presas é negra (62\%); jovem (o maior índice de presas estão na faixa etária de 18 a 29 anos) e com pouco ou nenhum estudo. Sendo que cerca de $66 \%$ da população prisional feminina ainda não acessou o ensino médio, tendo concluído, no máximo, o ensino fundamental; sendo que apenas $15 \%$ da população prisional feminina concluiu o ensino médio (BRASIL, 2017b).

Importante reforçar que são notórios os reflexos diretos que a precariedade da educação brasileira gera em outras áreas, como a da saúde, índices de mortalidade e principalmente no sistema carcerário. O Relatório do Desenvolvimento Humano 2013, publicado pelo Programa das Nações Unidas para o Desenvolvimento (PNUD) ${ }^{2}$ enfatiza a importância da educação da mãe no desenvolvimento, e na própria sobrevivência da criança, mais do que o rendimento familiar propriamente dito, o que evidenciam a necessidade de realizar políticas públicas destinadas a melhorar a educação de jovens do sexo feminino (PNUD, 2013, p. 06).

$\mathrm{O}$ direito à Educação é fundamental por ser um direito social diretamente vinculado ao direito à vida. Nesse sentido, Baruffi (2008, p. 45) afirma ser a educação um direito complexo, pois, é objeto de várias pretensões de direito "[..] A educação se apresenta como um interesse não apenas do sujeito individualmente considerado, mas como um direito coletivo, próprio da sociedade". Evidencia-se, assim, que o direito à educação carrega em si as características dos direitos da personalidade, ou seja, não se sujeita à vontade do legislador ou à boa vontade do Estado, pois trata-se de algo inerente à personalidade humana desenvolver, de acordo a própria estrutura e constituição humana (BITTAR, 2001, p. 158). Portanto, esse direito é imprescindível para o desenvolvimento da personalidade humana está intimamente ligado ao princípio da dignidade da pessoa humana.

O Direito à Educação é um direito importante para o desenvolvimento da pessoa e assume a função da construção da cidadania, sendo ela a precursora do pleno desenvolvimento do indivíduo e da construção de sua dignidade. Segundo Zenni (2011, p. 178) "No processo de educação é que a capacidade cognitiva do ser humano exprime-o como metafísico, vislumbra fins e constrói sua dignidade".

De acordo com o perfil das mulheres privadas de liberdade, delineado acima, resta evidente o quanto essas estatísticas revelam a vulnerabilidade e exclusão social, tendo em vista que em sua larga maioria, origem em classes populares, baixa instrução e exclusão do mercado formal de trabalho.

A seletividade do sistema penal se deve especialmente, segundo Andrade, a duas variáveis estruturais:

Em primeiro lugar, à incapacidade estrutural de o sistema penal operacionalizar, através das agências policial e judicial, toda a programação da Lei penal, dada a magnitude da sua abrangência, pois está integralmente dedicado a administrar uma reduzidíssima porcentagem das infrações, seguramente inferior a 10\%. Por outro lado, se o sistema penal concretizasse o poder criminalizante programado provocaria uma catástrofe social. [...] E diante da absurda suposição absolutamente indesejável - de criminalizar reiteradamente toda a população, torna-se óbvio que o sistema penal está estruturalmente montado para que a legalidade processual não opere em toda sua extensão. O que significa que não

\footnotetext{
${ }^{2}$ O Relatório do Desenvolvimento Humano "A Ascensão do Sul: Progresso Humano num Mundo Diversificado" de 2013 avalia igualdade de gênero, extrema pobreza e desigualdades no Índice de Desenvolvimento Humano, e analisa as questões e tendências emergentes, bem como os novos atores que moldam o panorama do desenvolvimento Disponível em: http://hdr.undp.org/sites/default/files/hdr13_summary_pt_web.pdf. Acesso em 05 Jan. 2019
}

Revista de Direito Brasileira | Florianópolis, SC | v. 24 | n. 9 | p.463-488 | Set./Dez. 2019 
adianta inflacionar o input do sistema, através da criação de novas leis porque há um limite estrutural ao nível do out pui (ANDRADE, 2003, p. 48).

A atuação seletiva do sistema de justiça penal ocasiona muitas violações e institui uma forma paradoxal de enfrentar a criminalidade. Os dados atuais mostram que a maioria dos detentos do sistema penitenciário brasileiro hoje é oriunda da parcela mais vulnerável da população. Assim, a prisão opera de modo extremamente funcional ao selecionar a população que se encontra na marginalidade social, e o que se visualiza é um sistema penal que se configura como uma instância do controle social, que nada mais é do que uma contínua seleção e reprodução das relações de desigualdade de produção, em conjunto com "outras formas de controle social formal e informal" (ÁVILA, 2013, p. 206).

Para Andrade (2007, p. 60), a seletividade é a função real e a lógica estrutural de funcionamento do sistema de justiça criminal, comum às sociedades patriarcais e capitalistas, $o$ que mais evidencia essa seletividade é a própria clientela da prisão ao revelar que a construção simbólica e instrumental da criminalidade incide estigmatizantemente sobre a pobreza e a exclusão social, majoritariamente masculina e residualmente feminina, apesar desta última se verificar um grande crescimento. Então, segundo a autora, o sistema de justiça criminal funciona como um mecanismo público integrativo do controle informal dirigido à mulher, reforçando o controle patriarcal, a estrutura e o simbolismo de gênero, ao criminalizar a mulher em algumas situações específicas e, principalmente, por reconduzi-la ao lugar de vítima, ou seja, "mantendo a coisa em seu lugar passivo" (ANDRADE, 2007, p. 66).

Para compreender como, onde e por que o crime de tráfico ocorre não são suficientes perguntas epistemologicamente construídas a partir da condição socioeconômica dessa parcela das mulheres. As pesquisas sobre o controle social precisam ultrapassar uma visão instrumentalista e funcionalista do mesmo, buscando formas multidimensionais de pensar o problema, tendo em vista os complexos mecanismos que produzem comportamentos considerados adequados ou não, com relação a determinada norma ou instituição social (ALVAREZ, 2004, p. 170). Este é o caso das mulheres criminalizadas e vitimadas.

As mulheres presas pelo tráfico de drogas não estão entre as grandes chefes, nem sequer são grandes consumidoras, são na verdade, a parte terciária do negócio, o elo mais fraco, a parte mais vulnerável ou a distribuição final (ARGUELLO; MURARO, 2015, p. 767). As relações de desigualdades de gênero também perpassam o mercado de ilicitudes, as mulheres ingressam ao mercado ilícito de drogas, seja pela posição desempenhada no sistema, seja por necessidades de ordem econômica e/ou pelas relações afetivas. Em regra, as mulheres reproduzem nessas organizações criminais os papéis associados ao feminino, como cozinhar, limpar ou realizar pequenas vendas, conseguindo ascender de posição somente quando mantêm atitudes de extrema subserviência às ordens dos chefes do tráfico. Há uma evidente referência à clássica divisão sexual do trabalho, que destina às mulheres o trabalho doméstico, normalmente não remunerado, que se reproduz no negócio das drogas (CORTINA, 2015, p. 761).

Existe a feminização da pobreza, ou seja, da consideração estatística e social de que a pobreza tem atingido de forma significativa as mulheres e orientado suas escolhas de vida, um aspecto importante é o fato de muitas mulheres não contam com a corresponsabilidade do pai na criação dos filhos, numa cultura baseada na ética do cuidado como parte da condição feminina, o que resulta na diretriz de que elas serão as responsáveis diretas pelo cuidado e sustento dos filhos, as mulheres tornam-se também chefes de família (MACEDO, 2008, p. 386).

A chefia familiar feminina, juntamente com outros fatores econômico-sociais, fundamenta a feminização da pobreza, sendo esta considerada como um dos aspectos para a compreensão do crescente aumento de mulheres no mercado ilícito das drogas e a sua criminalização, enquanto lógica seletiva do sistema penal. Nesse sentido, de acordo com Santos (2011, p. 45), o indicador do sistema penitenciário nacional escancara a ineficácia dos argumentos de reintegração social 
contraditoriamente ao seu papel segregador e vulnerabilizador de determinadas parcelas da sociedade.

O que se constata é que dentro do sistema penal as mulheres sofrem consequências pela invisibilidade, onde se ignora as especificidades gênero. Essa parcela da sociedade brasileira, merecem tratamento com igual respeito e consideração. Assim, através do princípio da dignidade da pessoa humana garante a proteção de todas as dimensões de forma conjunta e as muitas vertentes que compõe o são, essenciais à possibilidade de se concretizar materialmente os direitos da personalidade.

\section{MÃES EM SITUAÇÃO DE CÁRCERE}

$\mathrm{Na}$ atualidade, a omissão de formulações e cuidados referente às mulheres encarceradas está distante de ser apenas uma questão de peso demográfico, a disparidade marca a própria assimetria que se evidencia no debate impregnado pela lógica da dominação simbólica masculina (CUNHA, 2007, p. 82). Em uma constatação histórica sobre a temática prisões se demonstra como a reclusão masculina sempre estabeleceu parâmetros dessa discussão, a criminologia nasceu como discurso de homens para homens, sobre as mulheres, e no decorrer temporal se transformou em um discurso de homens, para homens e sobre homens (MENDES, 2017). De forma que, no discurso criminológico competente atual a mulher surge somente em alguns momentos, como uma variável, jamais como um sujeito

São nos casos de maternidade no cárcere que se destaca o improviso que se é tratado o sistema prisional feminino. A maioria das mulheres encarceradas são mães, de acordo com o último levantamento do INFOPEN são cerca de 74\% (BRASIL, 2017b), onde se verifica ocorrência de violências e penas cruéis que infelizmente se estendem às crianças. A gestação e maternidade no cárcere ainda são assuntos invisíveis e ignorados, até mesmo pela criminologia.

As presas gestantes que dão à luz seus filhos durante o encarceramento, vivem com eles em prisões insalubres, sob a vigilância constante e num contexto totalmente incompatível com um desenvolvimento afetivo, motor e psicossocial harmonioso (SIMAS et al., 2015, p. 551). Assim, as crianças que iniciam a vida no alojamento conjunto de uma prisão, são privadas de conviver na sociedade livre interferindo de maneira negativa no desenvolvimento do menor.

No Brasil a maioria das instituições prisionais não se adequam às reais necessidades femininas os cuidados com a saúde, tanto sexual quanto reprodutiva, os programas e ações públicas de apoio à maternidade e às famílias são negligenciados pelo Estado (SANTA RITA, 2006). A vulnerabilidade das mulheres em situação prisional é ampliada em razão dos bloqueios ao acesso a serviços de saúde, sociais e legais. Os filhos sentem diretamente os impactos dessas obstruções, gerando uma contínua rede de violações de direitos fundamentais.

A realidade das mães presas e as ações institucionais a elas afetas guarda enorme relação a dignidade da pessoa humana. $\mathrm{O}$ que se discuti nesse estudo é a importância da reflexão sobre questões amplas de reformulações de política criminal e alternativas que possibilitem uma execução penal feminina mais humanizada, tomando o princípio da dignidade como valor supremo.

Quanto a legislação pátria, a Constituição Federal em seu artigo $5^{\circ}$, incisos L e XLIX, prevê direitos fundamentais à população feminina carcerária, como o de amamentar os filhos e ter a integridade física e moral mantidas. $\mathrm{O}$ dever de proteção está previsto expressamente no artigo $6^{\circ}$, caput, e a assistência gratuita à criança de até seis anos de idade em creches e pré-escolas está preconizada no artigo $7^{\circ}$, inciso XXV da Constituição como direitos sociais. A Lei de Execuções Penais, por sua vez, estabelece que os estabelecimentos prisionais femininos contenham espaços para cuidados e amamentação de bebês de até 6 meses de idade; devendo as penitenciárias contar com creches destinadas a crianças entre 6 meses e 7 anos.

No âmbito internacional o Brasil é signatário dos Tratados Internacionais de Direitos Humanos relacionados à temática. Um exemplo que se pode citar é a Convenção sobre os Direitos 
da Criança (1989) que define o conceito de criança e estabelece parâmetros de orientação e atuação política de seus Estados-partes, visando ao desenvolvimento individual e social saudável da infância. As Regras de Bangkok, outro importante documento internacional importante, foram aprovadas em 2010 pela Assembleia Geral das Nações Unidas, e nelas são reafirmados direitos humanos relativos à maternidade, à família, à saúde da mulher e de seus filhos no cárcere. Outro exemplo é a Conferência Internacional da ONU sobre População e Desenvolvimento, realizada no Cairo, Egito (ONU, 1994).

Apesar dessa legislação protetora, se verifica ainda um grande silêncio institucional a respeito da questão da maternidade na prisão. No que tange a situação de mães e crianças no sistema prisional, o levantamento INFOPEN Mulheres, conforme já mencionado, revelou que 14\% das unidades femininas ou mistas contam com berçário e/ou centro de referência materno-infantil. E, apenas 3\% das unidades prisionais brasileiras declararam contar com espaço de creche (BRASIL, 2017b).

Isso comprova a negligência do Estado com relação às mulheres e às crianças do cárcere. Somente em 2016 foi realizado um plano nacional de atenção às mulheres que se encontram privadas de liberdade grávidas ou vivem com os filhos no cárcere (BRASIL, 2016). Apesar de se reconhecer um certo avanço, como marco legal, ainda existe uma sensação de incerteza quanto ao futuro, tendo em vista que, grande parte dessas mulheres são as únicas responsáveis pelos filhos fora do muro do cárcere

Sobre a realidade da mulher no cárcere Vieira e Veronese lecionam:

[...] há as unidades prisionais que não dispõem de médicos ginecologistas, mesas para ginecologia, esterilizadores de instrumentos ginecológicos nem remédios, dentre outras deficiências, o que significa que as consultas pré-natais ou têm de ser feitas fora do estabelecimento penal, ou quando feitas ali, padecem de precariedade de recursos e da deficiência de equipamentos e instrumentos médicos (VIEIRA; VERONESE, 2015, p. 169).

Sabe-se que a atenção e o cuidado oferecidos por parte dos profissionais à parturiente são essenciais para um parto saudável, humanizado, prevenindo a mortalidade infantil. Nesse viés, as Regras de Bangkok declaram na Regra 24 que instrumentos de contenção jamais deverão ser usados em mulheres em trabalho de parto, durante o parto e nem no período imediatamente posterior. No âmbito nacional, em 2008, foi editada a Súmula Vinculante $\mathrm{n}^{\circ} 11$ que torna exceção o uso de algemas ${ }^{3}$. Porém, apesar do enunciado ser claro, aconteceram reiterados casos de parturientes mantidas algemadas durante o parto.

Assim, diante da lacuna existente no artigo 199 da Lei de Execução Penal, foi publicado o Decreto $n^{\circ}$ 8.858/16 que regulamentou o emprego de algemas, sendo vedada sua utilização durante o trabalho de parto, no trajeto da parturiente entre a unidade prisional e a unidade hospitalar e após o parto, durante o período que se encontrar hospitalizada. O que se pretendeu aqui, foi garantir o respeito à integridade moral e física das presas, respeitando a dignidade da mãe e da criança.

Portanto, não obstante existir diversos instrumentos com base nos princípios dos direitos humanos, contendo referenciais de tratamento a ser dispensado às pessoas presas, ainda ocorrem muitos entraves na realidade atrás das grades, sendo comum a violência psicológica ou física decorrente da ação ou omissão dos agentes do Estado, como também da própria sociedade (SANTA-RITA, 2006). Observa-se, então, uma escassez de ações institucionais voltadas à mãe

\footnotetext{
${ }^{3}$ Súmula Vinculante ${ }^{\circ} 11$ : Só é lícito o uso de algemas em casos de resistência e de fundado receio de fuga ou de perigo à integridade física própria ou alheia, por parte do preso ou de terceiros, justificada a excepcionalidade por escrito, sob pena de responsabilidade disciplinar, civil e penal do agente ou da autoridade e de nulidade da prisão ou do ato processual a que se refere, sem prejuízo da responsabilidade civil do Estado.
} 
presa com criança em ambiente prisional, como a falta de espaços apropriados para o atendimento infantil, a inobservância do direito da criança à convivência familiar e comunitária, e a inexistência de políticas específicas voltadas à maternidade de modo geral.

Ressalta-se, assim, a importância do princípio fundamental à convivência familiar, incluso no art. 227, da Constituição Federal. Em sintonia com o direito da convivência familiar está a doutrina da proteção integral da criança e do adolescente, que foi introduzida no universo jurídico pela Convenção Internacional sobre os Direitos da Criança, e cristalizada no ordenamento pátrio pela Constituição Federal de 88, e, também, no Estatuto da Criança e do Adolescente (Lei $\mathrm{n}^{\circ}$ 8.069/1990).

A Corte Constitucional brasileira (STF) decidiu, em fevereiro de 2018, conceder habeas corpus coletivo $\mathrm{n}^{\circ} 143.641$ para determinar a substituição da prisão preventiva por domiciliar de mulheres presas, em todo o território nacional, que sejam gestantes ou mães de crianças de até doze anos ou de pessoas com deficiência, ressalvando a possibilidade das medidas alternativas previstas no artigo 319 do Código de Processo Penal.

O habeas corpus coletivo foi impetrado pelo Coletivo de Advogados em Direitos Humanos (embora a Defensoria Pública da União figure como impetrante no documento relativo ao voto do relator, Ministro Ricardo Lewandowski) para questionar um ponto que está na lei desde da reforma de 2016. O marco Legal da Primeira Infância em 2016 (Lei 13.257/2016), dentre várias alterações, alterou o artigo 318 do CPP. Esse artigo passou a determinar que mulheres que tiverem em prisão preventiva, e estiverem grávidas ou com filhos menores de até 12 anos, possuem o direito de concessão de prisão domiciliar.

Os principais argumentos lançados no pedido de habeas corpus gravitaram em torno da constatação de que a prisão preventiva, ao confinar mulheres grávidas em estabelecimentos prisionais totalmente precários, suga-lhes o acesso a programas de saúde básicos como: pré-natal, assistência regular na gestação e no pós-parto, privam-se as crianças de condições adequadas ao seu saudável desenvolvimento, a pena transcende a figura do apenado e constitui tratamento desumano, cruel e degradante, que viola os postulados constitucionais relacionados à individualização da pena, à vedação de penas cruéis e, ainda, ao respeito à integridade física e moral da mulher em situação de cárcere.

Deram ênfase no cabimento de habeas corpus coletivo como meio de defesa da liberdade de locomoção de determinados grupos de pessoas, baseado na garantia de acesso à Justiça, e considerado o caráter sistemático de práticas que resultam em violação maciça de direitos. Para isso, invocaram o art. 25, I, da Convenção Americana de Direitos Humanos, que garante o direito a um instrumento processual simples, rápido e efetivo, apto a tutelar direitos fundamentais lesionados ou ameaçados.

Vale lembrar que a natureza coletiva do habeas corpus impetrado endereçava a abrangência, generalização e o caráter sistêmico do problema. Na forma coletiva, o instrumento ganha a amplitude necessária à cessação das lesões ao direito de locomoção ora atacadas: o crescente encarceramento cautelar de gestantes, lactantes e mães com crianças de até 12 anos em estruturas prisionais precárias. Assim, a ação violadora tem impacto coletivo, a individualização do remédio obscurece as causas e, muitas vezes, faz persistir a ilegalidade.

O habeas corpus foi admitido ao fundamento de que é medida processual adequada para a tutela de grupos vulneráveis. O Ministro Ricardo Lewandowski (relator) e reconheceu a aplicabilidade desse remédio constitucional, em suas palavras:

Com maior razão, penso eu, deve-se autorizar o emprego do presente writ coletivo, dado o fato de que se trata de um instrumento que se presta a salvaguardar um dos bens mais preciosos do homem, que é a liberdade. Com isso, ademais, estar-se-á honrando a venerável tradição jurídica pátria, consubstanciada na doutrina brasileira do habeas corpus, a qual confere a maior amplitude possível ao remédio heroico, e que encontrou em Ruy Barbosa quiçá o seu maior defensor. 
Segundo essa doutrina, se existe um direito fundamental violado, há de existir no ordenamento jurídico um remédio processual à altura da lesão (Supremo Tribunal Federal, Habeas Corpus n ${ }^{\circ}$ 134.641/SP, Relator: Ministro Ricardo Lewandowski, Data de Julgamento: 20/02/2018, Segunda Turma).

A manifestação da Procuradoria-Geral da República sobre o não conhecimento do habeas corpus não merecia prosperar, tendo em vista que suas ressalvas de não ser possível a concessão de ordem genérica, sem individualização da sua beneficiária, deve ser analisada através do prisma de que coletividade paciente é uma coletividade selecionada e constituída pelo Estado brasileiro. Ou seja, para cada mulher em situação de cárcere reclusa preventivamente, há uma ordem de prisão concedida por autoridade judiciária. Assim, a nomeação dos integrantes desta coletividade é responsabilidade do Estado e a possível ocultação destes dados estatísticos não poderia se converter em ônus às pacientes e muro de proteção das autoridades coatoras (FRAGOSO et al., 2019, p. 17).

A decisão menciona a ADPF $347 \mathrm{MC} / \mathrm{DF}$ que reconheceu que o sistema prisional se encontra em um estado de coisas inconstitucional, onde se retrata a gravíssima deficiência estrutural carcerária, especificamente em relação à situação da mulher presa. Segundo Lewandowski, a decisão da Suprema Corte reconheceu:

[..] uma falha estrutural que agrava a "cultura do encarceramento", vigente entre nós, a qual se revela pela imposição exagerada de prisões provisórias a mulheres pobres e vulneráveis. Tal decorre, como já aventado por diversos analistas dessa problemática seja por um proceder mecânico, automatizado, de certos magistrados, assoberbados pelo excesso de trabalho, seja por uma interpretação acrítica, matizada por um ultrapassado viés punitivista da legislação penal e processual penal, cujo resultado leva a situações que ferem a dignidade humana de gestantes e mães submetidas a uma situação carcerária degradante, com evidentes prejuízos para as respectivas crianças (Supremo Tribunal Federal, Habeas Corpus $\mathrm{n}^{\circ}$ 134.641/SP, Relator: Ministro Ricardo Lewandowski, Data de Julgamento: 20/02/2018, Segunda Turma).

Assim, para reafirmar este estado precário e violador de direitos o ministro relator traz os dados do INFOPEN já cotejados anteriormente. Além disso, fundamenta sua decisão com base no arcabouço normativo brasileiro, como a Constituição em seu artigo $5^{\circ}$ incisos II, XLI, XLV, L, XLVIII e XLIX; bem como a própria Lei de Execução Penal e a Lei 11.942/2009 que promoveu mudanças na Lei de execução. E que, apesar das normas jurídicas presentes no ordenamento brasileiro, as autoridades responsáveis pelo sistema prisional não as tem respeitadas. $\mathrm{O}$ exemplo disso se constata na precariedade do acesso à Justiça das mulheres, a separação precoce de mães e filhos, internação das crianças mesmo quando há família extensa disponível.

Em síntese, os parâmetros para a substituição da prisão preventiva pela prisão domiciliar foram elucidados na conclusão do voto:

Em face de todo o exposto, concedo a ordem para determinar a substituição da prisão preventiva pela domiciliar - sem prejuízo da aplicação concomitante das medidas alternativas previstas no art. 319 do CPP - de todas as mulheres presas, gestantes, puérperas ou mães de crianças e deficientes, nos termos do art. $2^{\circ}$ do ECA e da Convenção sobre Direitos das Pessoas com Deficiências (Decreto Legislativo 186/2008 e Lei 13.146/2015), relacionadas neste processo pelo DEPEN e outras autoridades estaduais, enquanto perdurar tal condição, excetuados os casos de crimes praticados por elas mediante violência ou grave ameaça, contra seus descendentes ou, ainda, em situações excepcionalíssimas, as quais deverão ser devidamente fundamentadas pelo juízes que denegarem o benefício (Supremo Tribunal Federal, Habeas Corpus n ${ }^{\circ}$ 134.641/SP, Relator: 
Ministro Ricardo Lewandowski, Data de Julgamento: 20/02/2018, Segunda Turma).

Vale ressaltar, que apesar desse entendimento do tribunal e de todas as normas já existentes, ainda se depara com certa resistência do judiciário em ceder às prerrogativas aviltadas. Para superá-las, deve-se apostar no contínuo monitoramento e na insistente contestação. Ainda, cabe observar a necessidade do Judiciário e dos demais órgãos e atores, responsáveis pela gestão da liberdade de pessoas, conhecer a realidade sobre a qual intervêm e ponderarem o peso de suas ações e decisões.

Observa-se, então, uma escassez de ações institucionais voltadas à mãe presa com criança em ambiente prisional como: falta de espaços apropriados para o atendimento infantil (conforme os dados trazidos, anteriormente, sobre a situação dos berçários e creches); observância do direito da criança à convivência familiar e comunitária, e a inexistência de políticas específicas voltadas à maternidade de modo geral. Segundo Flávia Piovesan (2013, p. 287), a Convenção sobre Direitos da Criança, adotada pela ONU em 1989, e vigente desde 1990, é o tratado internacional de proteção de direitos humanos com grande número de ratificações. Esta Convenção acolhe a concepção do desenvolvimento integral da criança, reconhecendo-a como verdadeiro sujeito de Direito, a exigir absoluta prioridade e proteção especial.

A construção da doutrina integral, e consequentemente, do atual paradigma do Direito da Criança e do Adolescente, guarda subsídios de diversas outras áreas do saber. Profissionais do Serviço Social, da Psicologia, da Pedagogia, do Direito, dentre outras profissões, buscam alertar o jurista a respeito da importância de se reconhecer na criança e no adolescente, pessoas em fase peculiar de desenvolvimento e, por isso, merecedoras de proteção especial. Alguns estudos realizados na Universidade de Harvard demonstraram que a privação, na infância, de suporte psicológico e das experiências comuns às pessoas, produz danos ao desenvolvimento da criança (NELSON, FOX, ZEANAH, 2014).

A partir do exposto, se destaca a necessidade de se fazer uma revisão na legislação pertinente para garantir às necessidades específicas do gênero e buscar alternativas ao encarceramento para gestantes, mães ou responsáveis por infantes, como a aplicação de medida cautelar de prisão domiciliar. No Brasil há uma descaracterização de diretrizes de políticas públicas minimizadoras de violação da dignidade da pessoa humana. É necessário a implementação de políticas públicas que respeitem a pessoa e contemplem as particularidades abordadas anteriormente, por meio de uma perspectiva multidisciplinar de integração social.

\section{CONSIDERAÇÕES FINAIS}

O problema do presente estudo consistia em dar visibilidade a uma parcela da sociedade muito estigmatizada, esquecida e em situação de extrema vulnerabilidade, as mulheres encarceradas pelo sistema prisional brasileiro. Buscou-se, assim, ir além dos muros penitenciários para se compreender o aprisionamento feminino, tendo em vista que a grande parte das mulheres em situação de cárcere vivem em um cenário de descaso.

Por meio de uma perspectiva calcada na dignidade da pessoa humana como alicerce de todo o ordenamento jurídico e axioma justificante dos direitos da personalidade, considerando cada ser humano igual e possuidor do direito de desenvolver-se física e psiquicamente, procurou-se fazer uma reflexão sobre a dignidade da pessoa humana, começando desde evolução histórica da concepção de pessoa, passando para a análise do que é personalidade e direitos da personalidade, bem como suas características.

Se verificou que a personalidade é um complexo de caracteres do próprio indivíduo, consistindo na parte intrínseca da pessoa humana, decorrente da própria projeção da natureza humana seguindo a visão kantiana. Considerando a importância da proteção da pessoa e de sua 
personalidade eis que surge os Direitos de Personalidade. No trabalho buscou-se enfatizar a natureza de direitos subjetivos dos direitos da personalidade, sendo estes direitos inerentes à pessoa, por se tratar de diversos aspectos da manifestação da personalidade humana, e a importância da cláusula geral dos direitos da personalidade, instituída no ordenamento pátrio a partir da consagração da dignidade da pessoa humana como fundamento do Estado Democrático de Direito.

O estudo, quedou-se claro que a grande maioria das mulheres em situação de cárcere vivem em um cenário de negligência. Sendo a realidade brasileira marcada pelo processo de criminalização da miséria. Constatou-se, assim, que as ações institucionais vêm se desenvolvendo sem nenhum planejamento que leve em consideração a humanização da execução penal, violando direito a uma vida digna, principalmente referente a realidade de mães presas e seus filhos.

Concluiu-se que apesar da existência de uma Constituição garantidora de direitos e aderência em pactos humanos internacionais, não há correspondência entre o expresso nos instrumentos legais e normativos e a realidade que vivencia a mulher encarcerada. Buscou-se, também, analisar a maternidade no sistema carcerário brasileiro e os problemas decorrentes desta situação, fazendo principalmente uma análise em relação aos direitos constitucionais e garantias legais das presas gestantes e suas crianças.

$\mathrm{O}$ que restou evidente foi a dificuldade existentes das presas em acessar as garantias dispostas na legislação desde o período gestacional até o momento que a criança deverá se desligar da sua genitora. Os presídios femininos não se encontram preparados com berçários e creches para receberem infantes, submetendo-os a celas lotadas, falta de higiene, exposição a doenças e falta de estrutura, ou seja, as mínimas condições necessárias para uma sobrevivência digna são deficientes, ferindo, portanto, a Proteção Integral e o princípio da dignidade da pessoa humana.

\section{REFERÊNCIAS}

ALVAREZ, Marcos César. Controle social: notas em torno de uma noção polêmica. São Paulo Perspec. São Paulo, v. 18, n. 1, p. 168-176, março de 2004. Disponível em http://www.scielo.br/scielo.php?script=sci_arttext\&pid=S0102$88392004000100020 \& \operatorname{lng}=$ en\&nrm=iso. Acesso 10 Jun. 2019.

AMARAL, Francisco. Direito Civil: Introdução. 3. ed. Rio de Janeiro; São Paulo: Renovar, 2000.

ANDRADE, Vera Regina Pereida de. Sistema penal máximo x cidadania mínima: códigos da violência na era da globalização. 1. ed. Porto Alegre: Livraria do Advogado Editora, 2003.

ANDRADE, Vera Regina Pereira. A soberania patriarcal: o sistema de justiça criminal no tratamento da violência sexual contra mulher. Revista de Direito Público, n. 17, jul.-ago.set./2007.

AQUINO, São Tomás de. Suma de Teología. 4. ed. Madri: Biblioteca de Autores Cristianos, 2001.

ARGUELLO, Katie e MURARO, Mariel. Las mujeres encarceladas por tráfico de drogas em Brasil: las muchas caras de la violência contra las mujeres. Oñati Socio-Legal Series, Vol 5, no 2 , 2015. Disponível em: http://opo.iisj.net/index.php/osls/article/view/400. Acesso em 06 Jun. 2019.

ÁVILA, Gustavo Noronha de. Falsas memórias e sistema penal: a prova testemunhal em xeque. Rio de Janeiro: Lumen Juris, 2013. 
BARROSO, Luís Roberto. A Dignidade da Pessoa Humana no Direito Constitucional Contemporâneo: A Construção de um Conceito Jurídico à Luz da Jurisprudência Mundial. Belo Horizonte: Fórum, 2013.

BARUFFI, Helder. Educação como Direito Fundamental: um princípio a ser realizado. In: FACHIN, Zulmar (Coord.). Direitos Fundamentais e Cidadania. São Paulo: Método, 2008.

BASTOS, Celso Ribeiro; MARTINS, Ives Gandra. Comentários à Constituição do Brasil. São Paulo: Saraiva, 1988.

BITTAR, Eduardo C B; ALMEIDA, Guilherme Assis. Curso de Filosofia do Direito. 8 ed. São Paulo: Atlas, 2010.

BITTAR, Eduardo C.B. Direito e ensino jurídico: legislação educacional, São Paulo: Atlas, 2001.

BONAVIDES, Paulo. Teoria Constitucional da Democracia Participativa: por um Direito Constitucional de luta e resistência, por uma Nova Hermenêutica, por uma repolitização da legitimidade. São Paulo: Malheiros Editores Ltda, 2001.

BORGES, Roxana Cardoso Brasileiro. Direitos de personalidade e autonomia privada. 2.ed

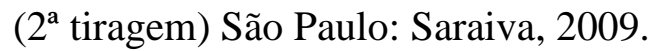

BUGLIONE, Samantha. O dividir da execução penal: olhando mulheres, olhando diferenças. In: CARVALHO, Salo (Org.). Crítica à execução penal. Doutrina, jurisprudência e projetos legislativos. Rio de Janeiro: Lumen Juris, 123-144, 2007.

CANTALI, Fernanda Borghetti. Direitos da personalidade: disponibilidade relativa, autonomia privada e dignidade humana. Porto Alegre: Livraria do Advogado, 2009.

CARLEN, Pat. Alternatives to women's imprisonment. Milton Keynes: Open University Press, 1990.

CARVALHO, Orlando de. A teoria geral da relação jurídica: seu sentido e limites. 2.ed. atual. Coimbra: Centelha, 1981.

COMPARATO, Fabio Konder. A afirmação histórica dos direitos humanos. 4.ed. São Paulo: Saraiva, 2014.

CORTIANO JUNIOR, Eroulths. Alguns apontamentos sobre os chamados direitos da personalidade. In: FACHIN, Luiz (org.). Repensando Fundamentos do Direito Civil Brasileiro Contemporâneo. Rio de Janeiro: Renovar, 1999.

CORTINA, Monica Ovinski de Camargo. Mulheres e tráfico de drogas: aprisionamento e criminologia feminista. Rev. Estud. Fem., Florianópolis , v. 23, n. 3, p. 761-778, Dec. 2015. Disponível em:

http://www.scielo.br/scielo.php?script=sci_arttext\&pid=S0104026X2015000300761\&lng=en\&nr m=iso. Acesso em: 08 Jun. 2019. 
CUNHA, Manuela Ivone P. P. da. A reclusão segundo o gênero: Os estudos prisionais, a reclusão de mulheres e variação dos contextos de identidade. In: AAVV. Educar o Outro: As Questões de Gênero, dos Direitos Humanos e da Educação nas Prisões Portuguesas, Coimbra, Publicações Humanas, 2007, p. 82. Disponível em: http//migre.me/sbr1Q. Acesso em: 08 Jan. 2019.

ESPÍNOLA, Eduardo Filho. Sistema do Direito Civil. Rio de Janeiro: Editora Rio, 1977.

FERMENTÃO, Cleide Aparecida Gomes Rodrigues. Análise Filosófica sobre o Princípio da Dignidade Humana como uma Nova Teoria de Justiça. REVISTA JURÍDICA CESUMAR. Mestrado, v. 16, p. 877-896, 2016. p. 892. Disponível em:

http://periodicos.unicesumar.edu.br/index.php/revjuridica/article/view/5211/2891. Acesso em 06 Jan. 2019.

FERMENTÃO, Cleide Aparecida Gomes Rodrigues. Os Direitos Da Personalidade Como Direitos Essenciais E A Subjetividade Do Direito. REVISTA JURÍDICA CESUMAR. Mestrado, v. 6, p. 241-266, 2006.

FRAGOSO, N. et al. Filhos e algemas nos braços: enfrentamento do encarceramento feminino e suas graves consequências sociais. In: Instituto Alana. (Org.). Pela liberdade: a história do habeas corpus coletivo para mães e crianças. 1ed.São Paulo: Instituto Alana, 2019, v. 1, p. 1020.

FREITAS, Pedro Ferreira de; MOTTA, Ivan Dias da. 3. O DIREITO À EDUCAÇÃO COMO DIREITO DA PERSONALIDADE E MÍNIMO EXISTENCIAL. REVISTA JURÍDICA DO CESUCA, [S.1.], v. 3, n. 6, p. 46-58, abr. 2016. ISSN 23179554. Disponível em: http://ojs.cesuca.edu.br/index.php/revistajuridica/article/view/950. Acesso em 05 Jun. 2019.

GONÇALVES, Diogo Costa. Pessoa e Direitos da Personalidade: fundamentação ontológica da tutela. Almedina, 2008.

HOFFE, Otfried. A democracia no mundo de hoje. Tradução Tito Livio Cruz Romão. São Paulo: Martins Fontes, 2005.

JUNG, Carl Gustav. O Desenvolvimento da Personalidade. 9ª ed. Petrópolis: Vozes, 2006.

KANT, Immanuel. Fundamentação da metafísica dos costumes e outros escritos. Tradução de Leopoldo Holzbach. São Paulo: Martin Claret, 2011.

KANT, Immanuel. Metafísica dos Costumes: introdução à doutrina da virtude. São Paulo. Edipro, 2012.

KLOCH, Henrique. MOTTA, Ivan Dias da. O Sistema Prisional e os direitos da personalidade do apenado com fins de res (socialização). Maringá: Verbo Jurídico, 2008.

LUISI, Luiz. Os Princípios Constitucionais Penais. 2. ed. rev. aum. Porto Alegre: Sergio Antônio Fabris Editor, 2003.

MACEDO, Márcia dos Santos. Mulheres chefes de família e a perspectiva de gênero: trajetória de um tema e a crítica sobre a feminização da pobreza. Caderno CRH, v. 21, n. 53, p. 385-399, 
ago. 2008. Disponível em: http://www.scielo.br/scielo.php?pid=S0103$49792008000200013 \&$ script=sci_arttext. Acesso em: 08 Jun. 2019.

MARCEL, Ferreira dos; Ávila, Gustavo Noronha de. Encarceramento em massa e estado de exceção do julgamento da ação de descumprimento de Preceito Fundamental 347. REVISTA BRASILEIRA DE CIÊNCIAS CRIMINAIS, v. 136, p. 267-291, 2017. p. 273-274.

MENDES, S. R. Criminologia Feminista: novos paradigmas - 2a. Edição. 2. ed. São Paulo: Saraiva, 2017. p. 215.

MORAES, Maria Celina Bodin de. O Conceito de Dignidade Humana: Substrato Axiológico e Conteúdo Normativo. In: SARLET,Ingo Wolfgang (Org.). Constituição, Direitos

Fundamentais e Direito Privado. Porto Alegre: Livraria do Advogado, 2003.

NELSON, Charles A., FOX, Nathan A. e ZEANAH, Charles H. Romania's Abandoned Children: Deprivation, Brain Development, and the Struggle for Recovery. Cambridge: Harvard Univ. Press, 2014.

PIOVESAN, Flávia. Direitos humanos e o direito constitucional internacional. 14 ed. São Paulo: Saraiva, 2013.

PNUD, 2013. Relatório do Desenvolvimento Humano. A Ascensão do Sul: Progresso Humano num Mundo Diversificado. Disponível em:

http://hdr.undp.org/sites/default/files/hdr13_summary_pt_web.pdf. Acesso em: 10 Mai. 2018.

REALE, Miguel. Nova Fase do Direito Moderno. 2 ed. São Paulo: Saraiva, 1998.

SAMPAIO, Danilo Fontenelle. A intervenção do Estado na economia e o princípio da dignidade da pessoa humana ante a nova lei ambiental. Revista CEJ, n. 1, Brasília, 2000.

SANTA RITA, Rosangela Peixoto. Mães e crianças atrás das grades: em questão o princípio da dignidade da pessoa humana. 2006. 162 p. Dissertação (Mestrado em Política Social)Universidade de Brasília, Brasília, 2006.

SANTOS, Raquel Costa de Souza. Maternidade no cárcere: reflexões sobre o sistema penitenciário feminino. 2011. Dissertação (Mestrado em Política Social) - Universidade Federal Fluminense, Niterói, 2011.

SARLET, Ingo Wolfgang. Dignidade da Pessoa Humana e Direitos Fundamentais na Constituição Federal de 1988. 7 ed. Porto Alegre: Livraria do Advogado, 2009.

SILVA, José Afonso da. Direito Constitucional Positivo. 17 ed. São Paulo: Malheiros, 2000.

SIMAS, Luciana; VENTURA, Miriam; BAPTISTA, Michelly Ribeiro e LAROUZE, Bernard. A jurisprudência brasileira acerca da maternidade na prisão. Rev. direito GV[online]. 2015, vol.11, n.2. p. 551. Disponível em:

http://www.scielo.br/scielo.php?script=sci_arttext\&pid=S180824322015000200547\&lng=en\&nr $\mathrm{m}=$ iso. Acesso em 08 Jun. 2019. 
STANCIOLI, Brunello Souza. Renúncia ao exercício de direitos da personalidade: ou de como alguém se torna o que quiser. Belo Horizonte: Del Rey, 2010.

SUPREMO TRIBUNAL FEDERAL, Habeas Corpus n 134.641/SP, Relator: Ministro Ricardo Lewandowski, Data de Julgamento: 20/02/2018, Segunda Turma. Disponível em:

https://portal.stf.jus.br/processos/detalhe.asp?incidente=5183497. Acesso em 10 Jun. 2019.

SZANIAWSKI, Elimar. Direitos de personalidade e sua tutela. $2^{\text {a }}$ ed. São Paulo: Revista dos Tribunais, 2005.

VIEIRA, Cláudia Maria Carvalho do Amaral; VERONESE, Josiane Rose Petry. Crianças encarceradas: a proteção integral da criança na execução penal feminina da pena privativa de liberdade. Rio de Janeiro: Lumen Juris, 2015.

ZENNI, Alessandro Severino Váller; FÉLIX, Diogo Valério. Educação para construção de dignidade: tarefa eminente do direito. REVISTA JURÍDICA CESUMAR - Mestrado, MaringáPR, vol. 11, n. 1, p. 169-192, jan./jun. 2011. p. 178. Disponível em: http://periodicos.unicesumar.edu.br/index.php/revjuridica/article/view/1736. Acesso em: 05 Jun. 2019. 